\title{
EXPOSURE OF OPERATING ROOM PERSONNEL TO ANAESTHETIC AGENTS: AN EXAMINATION OF THE EFFECTIVENESS OF SCAVENGING SYSTEMS AND THE IMPORTANCE OF MAINTENANCE PROGRAMS
}

\author{
A.M. Sass-Kortsak, I.P. WheEler, and J.T. Purdham
}

\begin{abstract}
Ten Alberta hospitals were monitored to assess the exposure of operating room personnel to nitrous oxide, halothane and enflurane during the average work day.

Exposure to these agents in operating rooms without scavenging systems was determined to be well above the recommended guidelines. Contaminants were significantly lower in operating rooms with scavenging systems of either the wall suction type or the air-conditioning exhaust type. ?

In the majority of studies, leakage points of anaesthetic gases were found throughout the anaesthesia systems. Where maintenance programs for the anaesthesia equipment were designed for the detection and elimination of leakage, contaminant levels were significantly lower than in those hospitals where the maintenance programs were concerned solely with proper equipment function as it relates to patient care.

A regular, frequent maintenance program for all anaesthesia and scavenging systems designed to identify and correct leakage points is therefore recommended. We consider a nitrous oxide monitor to be the ideal tool for detection of leakage.
\end{abstract}

Key WORDS: Operating ROOMS, contamination, exhaust systems.

SINCE THE MID-1960s epidemiological studies have shown a wide range of possible effects associated with expcsure of operating room personnel to anaesthetic gases and vapours. These include increased risk of spontaneous abortion, ${ }^{1-3}$ congenital abnormalities, ${ }^{4}$ low birthweight, ${ }^{5}$ malignancies, ${ }^{6}$ and renal and hepatic damage. ${ }^{2}$ In addition, reductions in cognitive, perceptual and motor skills have also been demonstrated in human volunteers ${ }^{7}$ exposed to anaesthetic agents. It should be noted, however, that other work-related factors may be associated with some of the health effects examined in the epidemiological studies. These factors include stress, exposure to X-ray, ${ }^{\mathrm{B}}$ and to hexachlorophene in scrubbing agents. ${ }^{9}$

The National Institute for Occupational Safety and Health (NIOSH) in the United States has recommended a standard for nitrous oxide of 25 parts per million (ppm) and $2 \mathrm{ppm}$ for halogenated anaesthetics, including halothane and enflurane. ${ }^{10}$ They consider these levels to be readily achievable, but there is no evidence to suggest that they are necessarily safe levels.

A.M. Sass-Kortsak, B.Sc., I.P. Wheeler, Ph.D., and J.T. Purdham, Ph.D., M.C.I.C., Occupational Hygiene Branch, Occupational Health and Safety Division, Alberta Workers' Health, Safety and Compensation.
The purpose of the present study was to determine to what extent Alberta operating room personnel were exposed to anaesthetic gases and vapours during the typical working day. Since the hospitals used a variety of scavenging methods, it also allowed for observation of the effectiveness of the different scavenging methods while in routine use. Further, where scavenging methods were in use, the impact of maintenance procedures on their effectiveness in reducing contamination to acceptable levels was investigated.

\section{Sampling Procedure}

Thirty-six operating rooms in ten hospitals were selected for inclusion in this study, each room being surveyed for two consecutive days. In six of the 10 hospitals, four rooms were examined, while in the remaining four hospitals, three rooms were examined.

A Miran 101 analyzer was used to measure concentrations of nitrous oxide in the operating room environment. A calibration chamber containing known concentrations of nitrous oxide was used to calibrate the instrument. It had been shown in a previous study that other operating room contaminants were unlikely to interfere with these measurements. ${ }^{14}$ 
Approximately 20 readings were taken for nitrous oxide in each operating room at random times throughout the working day. The sample probe was placed as close as possible to the anaesthetist's breathing zone without interfering with his work.

Glass tubes containing activated charcoal were connected to BENDIX BDX-44 Super Sampler pumps calibrated to draw air through the tubes at approximately $200 \mathrm{ml} / \mathrm{min}$. The exact volume of air drawn through the tube was determined from the calibrated flow rate and the time over which the sample was obtained. Two pumps were located in each operating room. One was placed near or on the anaesthetic machine and as close as possible to the anaesthetist's position. This sample was intended to reflect the anaesthetist's exposure and to detect local leakage in the anaesthetic machine. The second pump was located to one side of the room, close to the wall to reflect the exposure received by personnel in the areas of the operating room not immediatcly adjacent to the anaesthetic equipment.

In order to ascertain the time-weighted average exposure to halogenated anaesthetic vapours, the pumps were operated continuously from the beginning of the first operation to the closing of the operating room. After the samples had been obtained, the tubes were carefully sealed, labelled and returned to the laboratory for analysis. Halothane and enflurane were desorbed from the charcoal by shaking for 30 minutes with $1 \mathrm{ml}$ of carbon disulphide. The solution was then analyzed for halothane and enflurane content by gas chromatography using a Hewlett Packard 5800 gas chromatograph. A dual column technique was used to obtain resolution between the two agents. The chromatographic conditions were: a 3 feet $\times \frac{1}{8}$ inch stainless steel column packed with 20 per cent FFAP on 80/100 mesh Chromosorb W., followed by a 3 feet $\times \frac{1}{8}$ inch stainless steel column packed with 10 per cent TCEP and 10 per cent FFAP on 80/100 mesh Chromosorb $W$. The columns were operated isothermally at $50^{\circ} \mathrm{C}$ at a nitrogen carrier gas flow rate of $30 \mathrm{ml} / \mathrm{minute}$. It was necessary to precondition the system for thirty minutes at $150^{\circ} \mathrm{C}$ on each day of use. Detection was by a flame ionization detector, and the detection limits were $5 \mu \mathrm{g}$ per $\mathrm{ml}$ of carbon disulphide for halothane and 6 $\mu \mathrm{g}$ per $\mathrm{ml}$ of carbon disulphide for enflurane. Backup sections of the tubes were also analysed, and there was no evidence of halogenated anaesthetic breakthrough.
RESULTS

Scavenging systems were used in seven of the 10 hospitals included in this study, and could be divided into two types based on the exhaust method. In four hospitals a wall suction (vacuum) system associated with some form of reservoir unit was used, but this suction unit was not always used exclusively for scavenging. In three hospitals the exhaust vents of the nonrecirculating air-conditioning system were used for the scavenging. In two of these three hospitals the waste gases were vented through the ceiling or walls into the exhaust ducts in the crawl space. In the third hospital metal tubes were utilized to carry the gases directly into the exhaust grill located in an adjacent storage room. The remaining three hospitals included in the study did not have functioning scavenging systems.

In each operating room 14 to 25 readings for nitrous oxide were taken per day at random intervals. The number of readings depended upon the length of time the room was in use. It has been shown that such air contaminant measurements follow a log-normal distribution for which the geometric mean best describes the central tendency. "Consequently, daily means for each operating room were calculated as geometric means. The nitrous oxide analyzer used had a full scale reading of $300 \mathrm{ppm}$, and although several values were greater than this, they were assumed to be $300 \mathrm{ppm}$. Therefore, true geometric means for those rooms were actually somewhat greater than the values obtained.

The results obtained from the sampling for nitrous oxide, halothane and enflurane in each hospital appear in Tables I, II and III. No values are given for enflurane or halothane when these agents were not used. Figure 1 graphically illustrates the variation of nitrous oxide levels between operating rooms equipped with different scavenging systems. Figure 2 illustrates the effectiveness of a maintenance program in reducing airborne levels of nitrous oxide.

There was considerable variation in the manner in which each hospital maintained its anaesthetic equipment. For the purposes of this study a maintenance program was defined as one aimed at the detection and elimination of leakage of anaesthetic gases. In the four hospitals classified as having such a program, the maintenance of the equipment was carried out two to three times each year by hospital staff: in three cases by a trained technician and in the other by 
TABLE I

Nitrous Oxide: Daily Geometric Mean Concentrations (and Ranges) in pPM

\begin{tabular}{|c|c|c|c|c|c|c|c|c|c|}
\hline \multirow{2}{*}{$\frac{\text { Hospital }}{\mathrm{A}^{*}}$} & \multirow{2}{*}{$\frac{\text { Scaverging }}{\text { S1 }}$} & \multicolumn{2}{|c|}{$\begin{array}{c}\text { Operating Room } \\
\text { I }\end{array}$} & \multicolumn{2}{|c|}{$\begin{array}{c}\text { Operating Room } \\
\text { II }\end{array}$} & \multicolumn{2}{|c|}{$\begin{array}{l}\text { Operating Room } \\
\text { III } \\
\end{array}$} & \multicolumn{2}{|c|}{$\begin{array}{l}\text { Operating Room } \\
\text { IV }\end{array}$} \\
\hline & & $\begin{array}{l}18 \\
16\end{array}$ & $\begin{array}{l}(4-100) \\
(3-23)\end{array}$ & $\begin{array}{r}6 \\
12\end{array}$ & $\begin{array}{l}(3-45) \\
(3-30)\end{array}$ & $\begin{array}{l}6 \\
7\end{array}$ & $\begin{array}{l}(3-55) \\
(1-140)\end{array}$ & $\begin{array}{l}48 \\
50\end{array}$ & $\begin{array}{l}(12-80) \\
(9-250)\end{array}$ \\
\hline B & SI & $\begin{array}{l}14 \\
35\end{array}$ & $\begin{array}{l}(5-33) \\
(1->300)\end{array}$ & $\begin{array}{l}29 \\
19\end{array}$ & $\begin{array}{l}(1-78) \\
(2-110)\end{array}$ & $\begin{array}{l}49 \\
24\end{array}$ & $\begin{array}{r}(29-110) \\
(1-220)\end{array}$ & $\begin{array}{l}32 \\
60\end{array}$ & $\begin{array}{r}(6->300) \\
(12->300)\end{array}$ \\
\hline $\mathrm{C}$ & S1 & $\begin{array}{l}21 \\
26\end{array}$ & $\begin{array}{l}(1-110) \\
(2-55)\end{array}$ & $\begin{array}{l}15 \\
18\end{array}$ & $\begin{array}{l}(1-110) \\
(1-250)\end{array}$ & $\begin{array}{l}48 \\
19\end{array}$ & $\begin{array}{l}(0-220) \\
(1-88)\end{array}$ & $\begin{array}{l}19 \\
47\end{array}$ & $\begin{array}{r}(0-110) \\
(10-120)\end{array}$ \\
\hline $\mathrm{D}^{*}$ & SI & 13 & $(0-200)$ & $\begin{array}{r}11 \\
5\end{array}$ & $\begin{array}{l}(0-100) \\
(0-40)\end{array}$ & 7 & $(0-50)$ & $\begin{array}{r}6 \\
11\end{array}$ & $\begin{array}{l}(1-28) \\
(1-50)\end{array}$ \\
\hline$E^{*}$ & S2 & $\begin{array}{l}2 \\
2\end{array}$ & $\begin{array}{l}(0-5) \\
(0-22)\end{array}$ & $\begin{array}{l}48 \\
47\end{array}$ & $\begin{array}{l}(33-66) \\
(33-61)\end{array}$ & $\begin{array}{r}16 \\
7\end{array}$ & $\begin{array}{l}(0-220) \\
(0->300)\end{array}$ & $\begin{array}{r}12 \\
4\end{array}$ & $\begin{array}{l}(3-300) \\
(1-20)\end{array}$ \\
\hline F & S2 & $\begin{array}{l}22 \\
14\end{array}$ & $\begin{array}{l}(1-270) \\
(1-90)\end{array}$ & $\begin{array}{l}10 \\
72\end{array}$ & $\begin{array}{l}(0-35) \\
(1->300)\end{array}$ & $\begin{array}{l}5 \\
2\end{array}$ & $\begin{array}{l}(0-200) \\
(0-60)\end{array}$ & & \\
\hline $\mathrm{G}^{*}$ & S2 & $\begin{array}{l}43 \\
39\end{array}$ & $\begin{array}{r}(3-250) \\
(10-150)\end{array}$ & $\begin{array}{l}4 \\
9\end{array}$ & $\begin{array}{l}(0-240) \\
(1-200)\end{array}$ & $\begin{array}{l}23 \\
17\end{array}$ & $\begin{array}{l}(2-110) \\
(3-50)\end{array}$ & $\begin{array}{r}8 \\
10\end{array}$ & $\begin{array}{l}(2-95) \\
(1-110)\end{array}$ \\
\hline $\mathbf{H}$ & NS & $\begin{array}{l}43 \\
28\end{array}$ & $\begin{array}{l}(4->300) \\
(5-95)\end{array}$ & $\begin{array}{l}54 \\
51\end{array}$ & $\begin{array}{l}(2-130) \\
(3-160)\end{array}$ & 43 & $(3->300)$ & 61 & $(2->300)$ \\
\hline 1 & NS & $\begin{array}{r}147 \\
63\end{array}$ & $\begin{array}{r}(13->300) \\
(2->300)\end{array}$ & $\begin{array}{r}60 \\
115\end{array}$ & $\begin{array}{r}(0->300) \\
(17->300)\end{array}$ & $\begin{array}{l}36 \\
37\end{array}$ & $\begin{array}{l}(0->300) \\
(0-200)\end{array}$ & $\begin{array}{r}156 \\
78\end{array}$ & $\begin{array}{l}(40->300) \\
(23->300)\end{array}$ \\
\hline$J$ & NS & $\begin{array}{l}63 \\
31\end{array}$ & $\begin{array}{c}(40-90) \\
(7-100)\end{array}$ & $\begin{array}{r}55 \\
102\end{array}$ & $\begin{array}{l}(20->300) \\
(10-270)\end{array}$ & $\begin{array}{l}87 \\
98\end{array}$ & $\begin{array}{l}(12-150) \\
(30-180)\end{array}$ & & \\
\hline
\end{tabular}

S1-Wall Suction Scavenging, S2-Air Conditioning Exhaust Scavenging, NS-No Scavenging, *-Maintenance Program, GEN-General Room, ANA-Near Anaesthesia Machine, NU-Not Used.

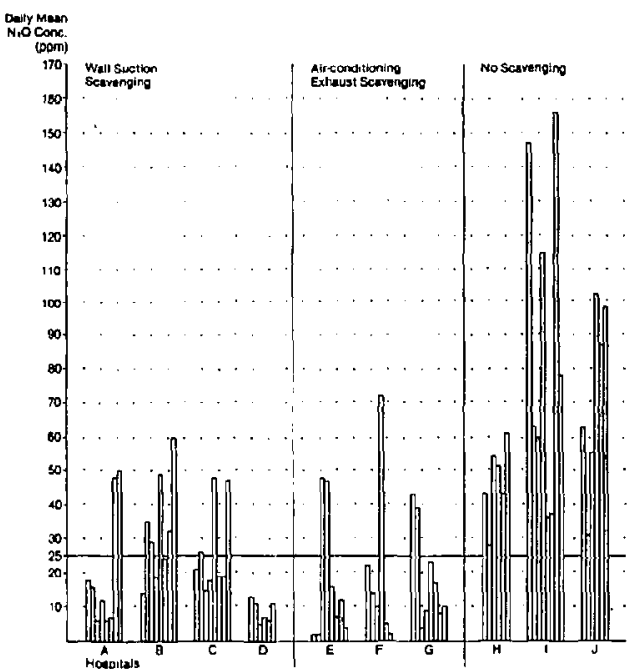

FIGURE 1 Daily Mean $\mathrm{N}_{2} \mathrm{O}$ Concentrations vs. Hospitals (Three Different Types of Scavenging).

an anaesthetist. In some of those hospitals classified as not having a maintenance program, the equipment was checked periodically, but only for proper working order in terms of patient care.
Statistical analysis for comparison between hospitals was carried out on the nitrous oxide data (Table I, Figures 1 and 2). The MannWhitney Test ${ }^{12}$ was used to make three comparisons:

(1) scavenged versus non-scavenged operating rooms;

(2) wall suction scavenging versus airconditioning exhaust scavenging; and

(3) within scavenged operating rooms, those with some form of leakage maintenance program versus those without such a program.

\section{(1) Scavenging versus non-scavenging}

All of the daily geometric mean nitrous oxide concentrations found in Hospitals $A$ through $G$ (scavenged) were grouped together and tested against the levels in Hospitals $H, I$ and $J$ (unscavenged). There was a statistically significant difference $(p<0.0001)$ in the degree of contamination between these two groups. Moreover, only 29 per cent of all daily geometric mean nitrous oxide concentrations found in operating rooms with scavenging were over the recommended guideline of $25 \mathrm{ppm}$, whereas all rooms without scavenging were in excess of $25 \mathrm{ppm}$. 
TABLE II

Halothane: Daily Time Weighted Ayerage Concentrations in PpM

\begin{tabular}{|c|c|c|c|c|c|c|c|c|c|}
\hline \multirow[b]{2}{*}{ Hospital } & \multirow[b]{2}{*}{ Scavenging } & \multicolumn{2}{|c|}{$\begin{array}{c}\text { Operating Room } \\
\text { I }\end{array}$} & \multicolumn{2}{|c|}{$\begin{array}{l}\text { Operating Room } \\
\text { II }\end{array}$} & \multicolumn{2}{|c|}{$\begin{array}{l}\text { Operating Room } \\
\text { III }\end{array}$} & \multicolumn{2}{|c|}{$\begin{array}{c}\text { Operating Room } \\
\text { IV }\end{array}$} \\
\hline & & Gen & Ana & Gen & Ana & Gen & Ana & Gen & Ana \\
\hline$A^{*}$ & S1 & $\begin{array}{r}<0.03 \\
0.06\end{array}$ & $\begin{array}{r}<0.03 \\
0.16\end{array}$ & $\begin{array}{r}0.07 \\
<0.03\end{array}$ & $\begin{array}{l}0.10 \\
0.56\end{array}$ & $\begin{array}{l}0.11 \\
0.05\end{array}$ & $\begin{array}{l}0.10 \\
0.07\end{array}$ & $\begin{array}{l}0.45 \\
0.07\end{array}$ & $\begin{array}{l}0.98 \\
0.14\end{array}$ \\
\hline B & SI & $\begin{array}{l}0.35 \\
0.33\end{array}$ & $\begin{array}{l}0.33 \\
0.44\end{array}$ & $\begin{array}{l}<0.02 \\
<0.04\end{array}$ & $\begin{array}{l}<0.02 \\
<0.04\end{array}$ & $\begin{array}{r}0.33 \\
<0.03\end{array}$ & $\begin{array}{l}0.55 \\
0.05\end{array}$ & $\begin{array}{l}0.43 \\
0.27\end{array}$ & $\begin{array}{l}0.70 \\
0.38\end{array}$ \\
\hline $\mathrm{c}$ & S1 & $\begin{array}{l}0.19 \\
0.21\end{array}$ & $\begin{array}{l}0.20 \\
0.30\end{array}$ & $\begin{array}{l}0.19 \\
0.48\end{array}$ & $\begin{array}{l}0.44 \\
0.62\end{array}$ & $\begin{array}{l}0.64 \\
0.14\end{array}$ & $\begin{array}{l}4.45 \\
0.25\end{array}$ & $\begin{array}{l}0.31 \\
0.86\end{array}$ & $\begin{array}{l}0.70 \\
0.78\end{array}$ \\
\hline $\mathrm{D}^{*}$ & S1 & 0.34 & 0.90 & $\begin{array}{c}<0.003 \\
0.02\end{array}$ & $\begin{array}{l}0.04 \\
0.05\end{array}$ & 0.05 & 0.08 & $\begin{array}{l}0.05 \\
0.08\end{array}$ & $\begin{array}{l}0.70 \\
1.30\end{array}$ \\
\hline$E^{*}$ & $\mathrm{~S} 2$ & $\begin{array}{l}0.06 \\
0.10\end{array}$ & $\begin{array}{l}0.15 \\
0.19\end{array}$ & $\begin{array}{r}<0.07 \\
0.03\end{array}$ & $\begin{array}{r}<0.07 \\
0.06\end{array}$ & $\begin{array}{l}0.04 \\
0.12\end{array}$ & $\begin{array}{l}0.10 \\
0.31\end{array}$ & $\begin{array}{c}0.04 \\
<0.006\end{array}$ & $\begin{aligned} & 0.06 \\
< & 0.006\end{aligned}$ \\
\hline $\mathbf{F}$ & $\mathrm{S} 2$ & $\begin{array}{l}0.15 \\
0.29\end{array}$ & $\begin{array}{l}0.16 \\
0.31\end{array}$ & $\begin{array}{l}0.11 \\
0.30\end{array}$ & $\begin{array}{l}0.19 \\
0.44\end{array}$ & $\begin{array}{l}0.50 \\
0.25\end{array}$ & $\begin{array}{l}0.66 \\
0.42\end{array}$ & & \\
\hline $\mathrm{G}^{*}$ & S2 & $\begin{array}{l}0.76 \\
0.33\end{array}$ & $\begin{array}{l}7.30 \\
0.48\end{array}$ & $\begin{array}{l}0.50 \\
0.42\end{array}$ & $\begin{array}{l}0.64 \\
0.48\end{array}$ & $\begin{array}{l}0.54 \\
0.20\end{array}$ & $\begin{array}{l}0.72 \\
0.13\end{array}$ & $\begin{array}{l}0.44 \\
0.32\end{array}$ & $\begin{array}{l}0.65 \\
0.25\end{array}$ \\
\hline $\mathbf{H}$ & NS & $\begin{array}{l}1.46 \\
0.35\end{array}$ & $\begin{array}{l}1.61 \\
0.50\end{array}$ & $\begin{array}{l}0.67 \\
0.77\end{array}$ & $\begin{array}{l}0.65 \\
0.90\end{array}$ & 0.17 & 0.22 & 0.22 & 0.14 \\
\hline I & NS & $\begin{array}{l}1.34 \\
1.08\end{array}$ & $\begin{array}{l}1.04 \\
0.91\end{array}$ & $\begin{array}{l}3.50 \\
\mathrm{NU}\end{array}$ & $\begin{array}{l}6.13 \\
\mathrm{NU}\end{array}$ & $\begin{array}{l}0.72 \\
3.80\end{array}$ & $\begin{array}{l}1.19 \\
4.80\end{array}$ & $\begin{array}{l}0.05 \\
1.17\end{array}$ & 1.52 \\
\hline $\mathbf{J}$ & NS & $\begin{array}{l}0.001 \\
0.02\end{array}$ & $\begin{array}{l}0.20 \\
0.03\end{array}$ & $\begin{array}{l}0.01 \\
2.62\end{array}$ & $\begin{array}{l}0.05 \\
1.25\end{array}$ & $\begin{array}{l}0 \\
0\end{array}$ & $\begin{array}{l}0.04 \\
0\end{array}$ & & \\
\hline
\end{tabular}

S1-Wall Suction Scavenging, S2-Air Conditioning Exhaust Scavenging, NS-No Scavenging, *-Maintenance Program, GEN-General Room, ANA-Near Anaesthesia Machine, NU-Not Used.

(2) Wall suction versus air-conditioning exhaust No significant difference was found between the two systems of scavenging. This is in agreement with NIOSH. ${ }^{13}$

\section{(3) Maintenance versus non-maintenance}

The operating rooms in hospitals with some form of effective maintenance had significantly lower $(p<0.01)$ levels of nitrous oxide than those without.

\section{Discussion}

The most obvious source of contamination in some hospitals is the escape of waste anaesthetic gases from anaesthetic equipment into the room because of the lack of an effective scavenging system. Figure 1 demonstrates the dramatic reduction in levels of contamination that were achieved through use of an effective scavenging system.

Where scavenging systems are installed it has been demonstrated that there are still numerous potential sources of contamination. ${ }^{13}$ The scavenging system itself can allow anaesthetic

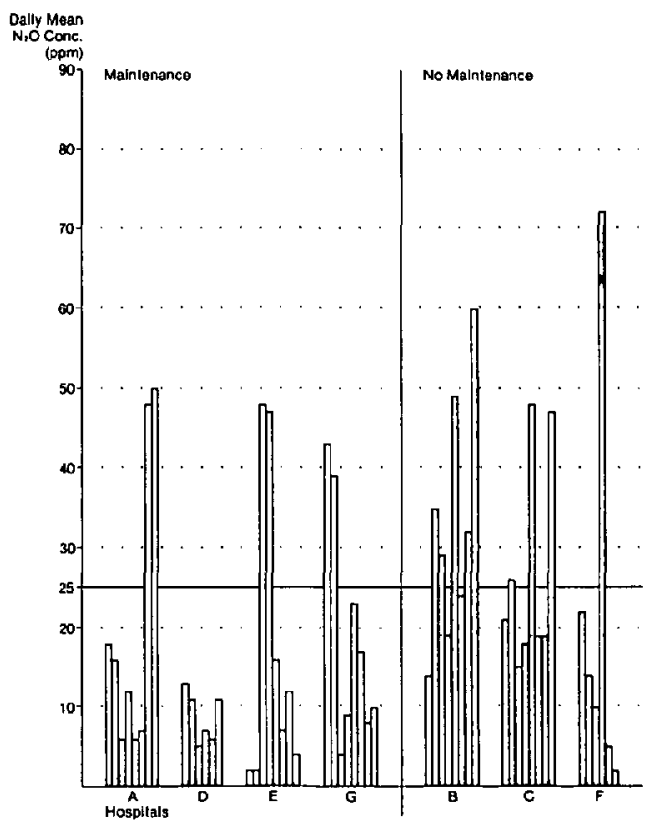

Figure 2 Daily Mean $\mathrm{N}_{2} \mathrm{O}$ Concentrations vs. Hospitals With and Without Maintenance Programs. 
TABLE III

Enflurane: Daily Time Weighted Average Concentration in PPM

\begin{tabular}{|c|c|c|c|c|c|c|c|c|c|}
\hline \multirow[b]{2}{*}{ Hospital } & \multirow[b]{2}{*}{ Scavenging } & \multicolumn{2}{|c|}{$\begin{array}{l}\text { Operating Room } \\
\text { I }\end{array}$} & \multicolumn{2}{|c|}{$\begin{array}{l}\text { Operating Room } \\
\text { II }\end{array}$} & \multicolumn{2}{|c|}{$\begin{array}{l}\text { Operating Room } \\
\text { III }\end{array}$} & \multicolumn{2}{|c|}{ Operating Room } \\
\hline & & Gen & Ana & Gen & Ana & Gen & Ana & Gen & Ana \\
\hline$A^{*}$ & S1 & 0.03 & $<0.03$ & 0.11 & $\begin{array}{l}0.17 \\
0.19\end{array}$ & 0.07 & 0.07 & 0.08 & $\begin{array}{l}0.16 \\
0.28\end{array}$ \\
\hline B & S1 & $\begin{array}{l}0.21 \\
0.32\end{array}$ & $\begin{array}{l}0.24 \\
0.33\end{array}$ & $\begin{array}{l}0.34 \\
0.80\end{array}$ & $\begin{array}{l}0.60 \\
2.16\end{array}$ & $\begin{array}{l}0.18 \\
0.21\end{array}$ & $\begin{array}{l}0.34 \\
0.43\end{array}$ & $\begin{array}{l}0.22 \\
1.13\end{array}$ & $\begin{array}{l}0.45 \\
1.53\end{array}$ \\
\hline $\mathrm{C}$ & S1 & $\begin{array}{l}0.41 \\
0.63\end{array}$ & $\begin{array}{l}0.46 \\
0.98\end{array}$ & $\begin{array}{l}0.07 \\
0.20\end{array}$ & $\begin{array}{l}0.10 \\
0.67\end{array}$ & $\begin{array}{r}0.15 \\
<0.01\end{array}$ & $\begin{array}{r}0.26 \\
<0.01\end{array}$ & $\begin{array}{l}<0.01 \\
<0.01\end{array}$ & $\begin{array}{l}<0.01 \\
<0.01\end{array}$ \\
\hline $\mathrm{D}^{*}$ & S1 & \multicolumn{2}{|c|}{ NU } & $<0.003$ & $<0.003$ & \multicolumn{2}{|c|}{ NU } & \multicolumn{2}{|c|}{ NU } \\
\hline $\mathrm{E}^{*}$ & S2 & \multicolumn{2}{|c|}{ NU } & \multicolumn{2}{|c|}{ NU } & \multicolumn{2}{|c|}{ NU } & \multicolumn{2}{|c|}{$\mathrm{NU}$} \\
\hline F & S2 & \multicolumn{2}{|c|}{$\mathrm{NU}$} & \multicolumn{2}{|c|}{ NU } & \multicolumn{2}{|c|}{ NU } & \multicolumn{2}{|c|}{ NU } \\
\hline $\mathrm{G}^{*}$ & S2 & \multicolumn{2}{|c|}{ NU } & \multicolumn{2}{|c|}{$\mathrm{NU}$} & \multicolumn{2}{|c|}{$\mathrm{NU}$} & \multicolumn{2}{|c|}{$\mathrm{NU}$} \\
\hline $\mathrm{H}$ & NS & \multicolumn{2}{|c|}{ NU } & \multicolumn{2}{|c|}{ NU } & 0.37 & 0.53 & 0.18 & 0.10 \\
\hline I & NS & \multicolumn{2}{|c|}{ NU } & NU & U 5.16 & \multicolumn{2}{|c|}{$\mathrm{NU}$} & \multicolumn{2}{|c|}{ NU } \\
\hline $\mathbf{J}$ & NS & $\begin{array}{l}0.94 \\
0.81\end{array}$ & $\begin{array}{l}2.92 \\
0.92\end{array}$ & $\begin{array}{l}1.02 \\
0.88\end{array}$ & $\begin{array}{l}2.58 \\
3.36\end{array}$ & $\begin{array}{l}1.25 \\
2.08\end{array}$ & $\begin{array}{l}2.53 \\
3.58\end{array}$ & & \\
\hline
\end{tabular}

S1-Wall Suction Scavenging, S2-Air Conditioning Exhaust Scavenging, NS-No Scavenging, *-Maintenance Program, GEN-General Room, ANA-Near Anaesthesia Machine, NU-Not Used.

gases and vapours to leak from pop-off valves, reservoir units or holes within the system. Leaks at connections, or in the lines of the high pressure nitrous oxide system, even if small, can lead to a considerable increase in the level of this contaminant in the operating room. Probably the most frequently encountered source of contamination is the low pressure system, particularly mechanical ventilators and carbon dioxide absorption circle units. In addition, respiratory hoses and tubing are vulnerable.

Contamination is also generated through poorly fitted masks and improperly inflated tracheal tube cuffs. Levels of halogenated anaesthetic agents can be increased by leakage from vapourizers, or from spills occurring while they are being filled.

The statistical comparison of the results obtained in hospitals using scavenging systems with those without them demonstrated that a scavenging system is effective in reducing contamination from anaesthetic gases significantly in operating rooms. A good general ventilation system alone was not sufficient to reduce this contamination to an acceptable level. This was illustrated in the case of Hospital $\mathrm{H}$, where the general ventilation (15-17 air changes per hour) was superior to that in Hospitals I and J (4-14 air changes per hour), while the levels of contami- nants were marginally less. Therefore, scavenging is still required to reduce the contaminants to levels below the recommended guidelines.

The statistical comparison of the results from those hospitals with maintenance programs to those without also showed a significant difference. Operating rooms were monitored under typical conditions, and it was not possible to account for every possible variable. For example, the use of mask techniques or especially high flow rates are liable to give rise to high levels of anaesthetic agents emitted from the machines. However, in order to cast doubt on the above result, hospitals without maintenance programs would have to use these techniques consistently more often than hospitals with maintenance programs. This was not found to be the case, and we are therefore confident in the validity of the result.

It is interesting to note that even in hospitals where mean nitrous oxide levels were below the guidelines, excursions beyond $300 \mathrm{ppm}$ sometimes occurred. To some extent, these excursions could be attributed to leakage. A number of additional factors were important. In some cases relatively high total flow rates were used by the anaesthetists and the wall suction units were not necessarily capable of exhausting such large volumes. Often, in these cases, the excess gases 
flowed into a reservoir unit (bag, hose, metal tube). If these units were open ended and excess gas volumes were sufficiently large, some gas may have been vented directly into the theater. Extra tubing or a larger reservoir bag may be used to increase the capacity of the system and thereby to alleviate the problem. The use of mechanical ventilators often contributed to these excesses. Small leaks could be exaggerated and new ones develop at weakened points, due to the positive pressure generated during the inspiratory phase.

With either type of scavenging system, consideration must be given to the fact that there are two different exhaust valves: one on the ventilator and one for the circle system. In some hospitals a Y-piece is used to connect both of these exhausts simultaneously to the scavenging system. Under these conditions the system should be designed so that the waste gases do not leak from one side (for example the circle system) directly into the unused ventilator. If a Y-piece is not used, the anaesthetists must remember to connect the scavenging system to the correct exhaust outlet.

Inspection of Tables II and III reveals that elevated levels of halothane and enflurane occurred primarily in those hospitals without scavenging systems. Particularly notable are Hospitals I and $\mathrm{J}$ which frequently exceeded 2 ppm, both in the anaesthetist's breathing zone and at the operating room periphery.

For the hospitals with scavenging systems there were only three occasions during this study where the guideline was exceeded. In all three cases the elevated levels were found near the anaesthetic machines, while the room periphery concentrations remained unremarkable. There are two possible explanations for these isolated peaks; either the vapourizers in question had developed leaks, or the vapourizers were filled during the sampling period and some spillage occurred. The latter may be eliminated by filling vapourizers after the daily slate of operations is completed, whenever possible, so that any contamination resulting from spillage is removed overnight by the general ventilation system. Alternatively, free standing vapourizers could be filled in a separate room.

It is apparent from the results that if nitrous oxide contamination is controlled to acceptable levels, then the concentration of the halogenated anaesthetic agents will, under typical conditions, also be within the guidelines unless significant vapourizer leakage occurs. Consequently, measurements of nitrous oxide levels are normally sufficient to determine the effectiveness of the scavenging system or the existence of leaks within the anaesthetic equipment. It should be noted, however, that this procedure will not identify leaks of halogenated anaesthetic agents from vapourizers.

Personnel employed in operating rooms without scavenging systems are being exposed to unacceptably high concentrations of anaesthetic agents. Under typical conditions in Alberta hospitals, exposure still exceeds recommended guidelines on occasion, even when scavenging systems are in place. This is especially true when an effective maintenance program which pays attention to leakage is not in place. Since exposure to anaesthetic agents may pose a potential health risk to these personnel, effective scavenging devices should be installed in all operating rooms and these devices, together with the anaesthetic equipment, should be properly maintained and regularly checked for leakage, preferably with a nitrous oxide monitor.

\section{ACKNOWLEDGEMENTS}

The authors wish to thank the Laboratory Services Branch, Alberta Worker's Health, Safety and Compensation for the analysis of halogenated anaesthetics and the Research and Education Branch for assistance with the statistical analysis. We would also like to thank Professor J.W.R. McIntyre, University of Alberta Hospital for the loan of equipment and his advice.

\section{REFERENCES}

1. Occupational disease among operating room personnel: report of an ad hoc committee on the effect of trace anesthetics on the health of operating room personnel. Anesthesiology 4l: 321 (1974).

2. SPence, A.A., Cohen, E.N., Brown, JR., B.W., KNILl-Jones, R.P. \& Himmelaurger, D.U. OCcupational hazards for operating room-based physicians, J.A.M.A. 238: 955 (1977).

3. Cohen, E.N., Beuville, J.W. \& Brown, Jr., B.W. Anesthesia, Pregnancy, and Miscarriage: A study of operating room nurses and anaesthetists. Anesthesiology 35: 343 (1971).

4. Corbett, T.H., Cornell, R.G., Enders, J.L. \& LIEDING, $K$. Birth defects among children of nurse-anesthetists. Anesthesiology 41:341 (1974).

5. Pharoah, P.E.D., Alberman, E. \& Doyle, P. Outcome of pregnancy among women in anesthetic practice. Lancet $l: 34$ (1977).

6. Corbett, T.H., Cornell, R. G., Lieding, K. \& ENDRES, J.L. Incidence of cancer among Michigan nurse-anesthetists. Anesthesiology 38: 260 (1973).

7. BRUCE, D.L. \& BACH, M.J. Effects of trace anesthetic gases on behavioural performance of volunteers. Br. J. Anaesth. 48: 871 (1976).

8. Vessey, M.P. Epidemiological studies of the occu- 
pational hazards of anesthesia - a review. Anesthesia $33: 430(1978)$.

9. Halling, H. Suspected link between exposure to hexachlorophene and birth of malformed infants. Lakartidningen $74: 542$ (1977).

10. Criteria for recommended standard - Occupational exposure to waste anesthetic gases and vapours. HEW Publication No. (NIOSH) 77-140. U.S. Department of Health, Education and Welfare (1977).

11. LeIDEL, N.A. \& BusCh, K.A. Statistical methods for the determination of non-compliance with occupational health standards. HEW Publication No. (NIOSH) TR-76. U.S. Department of Health, Education and Welfare (1976).
12. Soral, R.R. \& Rohlf, F.J. Biometry, Ist Ed. San Francisco: W.H. Freeman and Co., pp. 391-395 (1969).

13. Whitcher, C., Piziali, R., Sher, R. \& Moffat, R.J. Development and evaluation of methods for the elimination of waste anesthetic gases and vapours in hospitals. HEW Publication No. (NIOSH) 75-137. U.S. Department of Health, Education and Welfare (1975).

14. Mcintyre, J.W.R., Purdham, J.T. \& Hosein, H.R. An assessment of operating room environment air contamination with nitrous oxide and halothane and some scavenging methods. Canad. Anaesth. Soc. J. $25: 499$ (1978).

\section{RÉSUMÉ}

La contamination de l'atmosphère des salles d'opération par le protoxyde d'azote, l'halothane et l'enflurane au cours d'une journée de travail moyenne a été étudiée dans dix hopitaux d'Alberta. Dans les endroits où il n'y avait pas de système d'évacuation des gaz et des vapeurs anesthésiques, les taux de contamination étaient bien au-dessus des minima recommandés, alors que la contamination de l'air ambiant était significativement inférieure dans les endroits où un système de vidange était utilisé (succion murale ou remplacement de l'air dans un système à air conditionné sans recirculation). La vérification des appareils d'anesthésie a permis de déceler des fuites de gaz dans la majorité des cas. Les taux de contamination de l'atmosphère des salles d'opération étaient significativement inférieurs dans les hôpitaux où une vérification systématique des fuites au niveau des appareils d'anesthésie était effectuée dans le cadre d'un programme d'entretien et de vérification de l'équipement d'anesthésie.

Un programme régulier et fréquent de vérification et correction des fuites au niveau des appareils d'anesthésie et des systèmes de vidange des gaz et vapeurs anesthésiques est recommandé. Un moniteur de protoxyde d'azote nous apparaît comme l'appareil idéal pour la détection des fuites. 